\title{
How Did We Engage Resettled Chin Youth in Critical STEM Literacy Practices?
}

\author{
Minjung Ryu \\ Corresponding author, \\ Department of Chemistry, Learning Sciences Research Institute, \\ University of Illinois at Chicago \\ Chicago, IL, 60607, USA \\ mjryu@uic.edu
}

\author{
Shannon Mary Daniel \\ Department of Teaching and Learning, Vanderbilt University \\ Nashville, TN, 37203, USA \\ shannon.m.daniel@vanderbilt.edu
}

Received: 15July 2020 | Revised: 2 November 2020 |

Accepted: 16 November 2020

\begin{abstract}
Project RESET engaged resettled Chin refugee teens in critical STEM literacy practices in a community-based afterschool STEM enrichment program in the United States. Over the course of nine months, the participants multimodally and multilinguistically communicated their learning about weather, climate, and climate change, while also developing English proficiency. In this paper, we define critical sтEM literacy drawing on current scholarship on critical science literacy and interdisciplinary sт в M learning. We then present our four design principles of the learning environment for supporting critical sтем literacy and English learning and share examples from the program that demonstrate how the principles were enacted to engage youth. Drawing on our learning in this work, we will discuss implications for science educators who work with displaced or resettled youth in Asia and the Pacific regions that provide new homes for many displaced children and teens.
\end{abstract}




\section{Keywords}

refugee - afterschool - critical STEM literacy

$$
\text { 초록 (한국어) }
$$

전세계적으로 매년 수천 명이 넘는 난민들은 생명을 위협하는 자국을 떠나 새로운 나라, 혹은 새로운 대륙으로 이주한다. 이 중 대략 절반은 학령기 아동이나 청소년 이다. 미국에 도착하는 난민 배경 학생들의 대부분은 영어를 제 2 혹은 제 3 외국어 로 배우는 영어 학습자이고, 이주 과정에서 학교 교육을 정상적으로 받지 못한 경 우 또한 상당수이다. 이 연구의 저자들은 미국에 정착한 난민배경 학생들의 스템 (STEM) 학습을 지원하기 위한 공동체 기반 방과후 프로그램을 개발하여 시행하였 다. 연구 대상은 미국 중서부의 한 도시에 정착하여 공동체를 형성한 미얀마의 친 (Chin) 족 재정착 난민 배경의 고등학생들이며, 프로그램 목표는 학생들이 날씨, 기 후, 기후변화에 대해 배우면서 비판적 과학 문식성을 기르는 것이었다. 이 연구논문 에서 저자들은 최근의 연구 동향을 바탕으로 하여 비판적 과학 문식성이 무엇인지 먼저 논의한다. 이 정의를 바탕으로 하여 친 족 학생들의 비판적 과학 문식성과 영 어 습득을 함께 지원하는 방과후 프로그램을 어떻게 개발하였는지에 대한 개발 원 칙을 논의한다. 또한 이 연구를 토대로 하여 난민배경의 학생들이 점점 늘어나는 아 시아 태평양 지역에의 과학 교육에 대한 시사점을 제공하고자 한다.

\section{Introduction}

Every year, thousands of people migrate between countries to flee conflict or persecution. In 2019, there were more than 26.o million refugees around the globe, mostly originating from Syria, Afghanistan, South Sudan, Myanmar, and Somalia (United Nations High Commissioner for Refugees [UNHCR], 2O19a). By 2019 in the Asia and the Pacific region, roughly 7.7 million people were displaced from their homes as refugees, internally displaced people, and/or stateless people. The highest populations of refugees in Asia come from Afghanistan and Myanmar (formerly known as Burma). More than $85 \%$ of these Afghan and Myanmar refugees live in neighboring countries, such as Pakistan and Iran for Afghans, and Bangladesh, Malaysia, and Thailand for Burmese (UNHCR, 2018-2019).

Roughly half of these refugees around the world are school-aged children and adolescents under the age of 18 . These youths' schooling is interrupted in the process of migration, asylum-seeking, and resettlement in a third country. Refugee youths face multiple challenges in new countries. In schools, they 
have to learn new language(s), cultural practices, and school norms while learning new academic content. In addition, they often encounter mental health issues due to traumatic experiences in their home country or migration processes. Many of them have limited access to high quality science education because they live in impoverished neighborhoods or are subjugated to school systems' tracking practices that assign them to lower-level science classes. At the classroom level, these learners are often silenced by implicit and explicit English-only classroom norms (Gutierrez, Baquedano-López, \& Tejeda, 1999; Ryu \& Tuvilla, 2018), and many teachers believe that they should emphasize and foreground specific science vocabulary instead of prioritizing meaningmaking practices and building on students' knowledge resources (Settlage, Madsen, \& Rustad, 2005). It is imperative to understand these young learners' STEM learning experiences and find ways to engage them in meaningful learning experiences.

In response to this context, we designed an afterschool program, Project RESET, that engages resettled Chin (an ethnic group from Myanmar) youth in STEM learning practices that build on their strengths, developing critical sTEM literacy and building language competence. The purpose of this paper is to discuss critical STEM literacy, present design principles that we employed in designing an afterschool learning environment in order to advance resettled refugee teens' critical Sтем literacy, and share outcomes from the data collected throughout the program implementation. In what follows, we first briefly introduce the participants of Project RESET focusing on the modern history of British colonization and interethnic conflicts.

\section{Background Information on the Participants in Project RESET: Chin Refugees ${ }^{1}$}

Chin is an ethnic minority group in Myanmar (previously Burma) that is made up of over 30 ethnicities that reside in different mountainous villages where they have established their own culture, language, and economic system. Most Chin people are Christian. More than 200,ooo Chin asylum seekers and refugees were living in countries around the world in 2014 (Chow, 2018). The inter-ethnic conflicts in Myanmar trace back to the British colonization between 1824 and 1948. Before the British arrival, the land now known as Myanmar was inhabited by ethnic groups that formed villages and village tracts (clusters of villages). Multiple

1 This section primarily builds on a comprehensive review of ethnic conflicts in Myanmar by Jolliffe (2015). 
kingdoms, especially in low Burma (Irrawaddy delta in the southern part of Myanmar and surrounding coastal regions), and local leaders administered the villages and village tracts with varying governing authorities. In the mountainous area, such as today's Chin State, the political organizations were rather limited and administered weaker political structures due to the frequent movement of the populations. These mountain people had also not had much interaction with the strong kingdoms in low Burma because the mountainous areas and their economies did not present economic or other benefits to the lowland kingdoms.

Early in the colonization period, the British administration allowed these mountainous regions to be autonomous, as long as they paid taxes and tribunes and maintained British order, for the same reason they had been left along previously: the limited profitability of such regions. These areas were considered to be a "Frontier Areas." In the meantime, low Burma was rapidly centralized by the government of Bamar (the majority ethnic group of Burma), which resulted in the restriction of local rulers' power. Part of such an endeavor includes the British administration's rigid ethnic categorization to represent ethnic groups that share close ethnic and linguistic lineages - categories artificially labeled by the British government after colonization. This is when the current terms such as Karen, Kachin, Karenni, and Chin were first invented to refer to these ethnic categories. Between 1920 and 1945, multiple political groups emerged in the Frontier Areas to seek a certain level of coherence, political authority, and independence from Burma and the British administration. When the British left the country in 1945 and agreed to give Burma (majority Bamar) its independence, ethnic minority groups demanded their own autonomy and status equal to Bamar. The historic Panglong Agreement in 1947 promised the full autonomy of ethnic minority groups, and the constitution was established to decentralize the country's governmental power to states formed by ethnic minority groups. However, the agreement and constitution did not fully reflect demands of some non-Bamar ethnic leaders nor was the agreed-upon autonomy guaranteed. Part of the conflict was caused by the constitution's promotion of Buddhism as the Burmese national religion, while some ethnic groups were mainly Christian or Muslim. Unsatisfied ethnic leaders formed their own states, such as the Chin state.

In 1962, the central government became militarized through the coup led by General Ne Win. During this military regime, armed conflicts continued between armed forces of Burma and armed ethnic actors who claimed their autonomy. The centralization effort of the military regime included its control over education, natural resources (e.g., oil and gas), and security in ethnic minority states. The Burmese government implemented strong programs to spread the Burmese language in schools of ethnic minority groups, suppressing 
the use of ethnic languages. In more recent years, leaders of Bamar and nonBamar ethnic groups have made attempts to end the long-standing civil war. In 2011, a new Myanmar government was established, and, since then, Myanmar has undergone a series of reforms in its politics, economy, and administration aimed at democratizing the country. Also, ceasefires have been signed by multiple ethnic groups. Yet armed conflicts between Myanmar Armed Forces (Tatmadaw) and ethnic armies continue until today, and many people, especially those in Western Myanmar (Rakhine and Chin States), are displaced from their homes (UNHCR, 202O).

By 2018, approximately 160,000 Burmese refugees from all seven non-Bamar ethnic groups had resettled in the United States (Winn, 2017). Among these, more than 14,000 Chin people have resettled in Midwest City ${ }^{2}$ in the central United States. On the south side of Midwest City, Chin people have established an ethnic enclave where Chin people own businesses and have formed microcommunities around Chin churches. Churches are typically organized by their members' ethnicity, and those members also speak a shared home language. Burmese Organization (BO) is a non-profit organization founded in 2011. Its mission is to support Burmese Americans through advocacy, education, and employment whereby the community can thrive and be self-sufficient and integrated. While Chin ethnic churches typically serve a particular ethnicity within Chin people who share a common language, во functions as a center that gathers all Chin people regardless of their ethnicities. As a part of their education program, во offers an afterschool program throughout the school year and summer camp for high school youth. The afterschool program provides homework help facilitated by volunteers, support in college applications, and a safe space for young people to hang out. The summer camp engages teens in participatory action research in which they research issues that Burmese communities are facing through collecting literature and data, writing a paper, and presenting to community members and supporters. Our STEM enrichment program was designed as a part of the year-round afterschool program.

Most youth participants in the program were born in Chin State, migrated to Malaysia, their first asylum country, where they stayed for from several months to years, and resettled in the United States. Schooling experiences prior to entering the United States vary widely. Some teens who arrived in the United States before school age had not had any schooling experience in Burma. Most others, however, had attended schools in Chin State for varying lengths of time. Some teens had a form of education in Malaysia (operated by Chin people), whereas others did not have any education while in Malaysia. Those who went

2 Names of the program, location, and city in the United States are all pseudonyms. 
to a school in Malaysia learned English in preparation for resettlement in the United States, although some students said English learning in Malaysia was not helpful when they first arrived in the United States. Because of their varying education backgrounds and years of living in the United States, the participants' English proficiency varied widely as well.

\section{Critical STEM Literacy in an Afterschool Setting}

In designing a STEM afterschool program to engage Chin youths, we sought to engage the youths in the practices of critical STEM literacy. We aligned ourselves with the recent criticism on traditional science literacy. Traditional views on science literacy, or STEM literacy, define science as a set of knowledge products that are static and finalized rather than malleable and always negotiated (Olitsky, Flohr, Gardner, \& Billups, 2010). Thus, the oft-cited goal of science education, "science literacy for all students," is equated with everyone's attainment of certain knowledge and practices that are decontextualized and detached from learners' lives (Bang \& Vassoughi, 2016). This perspective makes a faulty assumption that educational equity means equality in the inputs (e.g., providing equally good instruction) and outputs (e.g., everyone attains predetermined levels of performance in standardized tests) and fails to raise fundamental questions about what counts as knowledge and learning and who owns the power to determine knowledge and learning.

To address this concern, a number of scholars have forwarded the concept of critical science literacy. They challenge the status quo definition of science and argue that science is an integral part of individuals' everyday lives and is tightly entangled with and dialogically related to various dimensions of learners' lives. Thus, science learning is a meaning-making process shaped by, for instance, individuals' experiences, intuition, imagination, and cultural sociopolitical values and is constantly negotiated within a meaning-making community. They thus assert that science education must aim to engage learners in developing critical science literacy. Rather than obtainment and retention of knowledge or advancement along the pre-determined science career pipeline, critical science literacy seeks for a transformation in the discourses and practices of science (e.g., Upadhyay \& Albrecht, 2011), learners' identities (e.g., O'Neill, 2011), and the world around them in order to build democratic and just societies (e.g., Emdin, 2011). In this perspective, educational equity is less about achievement of functional literacy equally by everyone and more about how individual learners enact critical agency that recognizes such transformative purposes and view themselves as agents for the transformation (Tan et al., 2012). 
Our STEM enrichment program and research around it built on the idea of critical science literacy. We aimed to engage learners in critical STEM literacy practices, defined as the dialogic reading and composition of STEM ideas that can transform individuals, communities, and global societies. By STEM, we mean inevitable entanglement of science and other closely related disciplines, including engineering, technology, mathematics, agriculture, and health. Our focus on STEM reflects the current interest in integrated STEM education (Kang, 2019; National Academy of Engineering and National Research Council, 2014; Srikoom, Hanuscin, \& Faikhamta, 2017). Instead of teaching science, technology, engineering, and mathematics as separate disciplines, teaching them in an inter- and trans-disciplinary way presents a potential to enable learners to solve real-world problems (such as climate change and community concerns) by connecting knowledge and epistemology of various disciplines (International Technology Education Association, 2007; NGSs Lead States, 2013; The National Council for Agricultural Education, 2015). We acknowledge this potential while also cautioning STEM education for the purpose of promoting elitist, economic, and colonial agendas (Williams, 2011). Moving away from a provision of top-down, sometimes artificial, integration of these disciplines for extrinsic motivation, our use of STEM acknowledges the blurry and arbitrary boundaries between these disciplines, allows an expansion of the repertoires of knowledge and practices of each discipline, and encourages learners to integrate these disciplines as needs arise.

Finally, we recognize that afterschool and informal programs can provide rich opportunities to engage youth from non-dominant backgrounds in critical stem literacy practices. Afterschool and informal programs are free from the curricular restrictions of formal schools and allow the merging of everyday knowledge with new ideas and skills (e.g., Bang \& Medin, 2010; Bell, Lewenstein, Shouse, \& Feder, 2009; Booker \& Goldman, 2016; Calabrese Barton \& Tan, 2010). Successful STEM afterschool programs connect with and draw upon cultural resources, values, and home practices (National Research Council, 2015). Despite the potential of afterschool sTEM enrichment programs in engaging youth from non-dominant backgrounds, resettled refugee youths have limited access to them (Lee \& Hawkins, 2008). This strong potential and limited reach of afterschool STEM programs provide a motivation for our work.

\section{$4 \quad$ Four Design Principles of Project RESET}

In this section, we discuss the four design principles employed in designing the learning environment in Project Reset. The goals of Project Reset were 
to advance participants' critical STEм literacy while facilitating development of their English competency simultaneously (see National Academies of Sciences, Engineering, and Medicine, 2018, for discussion about English learners' co-development of science and English literacy). To design an afterschool program toward these goals, we identified four design principles through an extensive review of critically oriented research literature in the areas of science education and literacy education. While the reviewed literature spans across multiple research frameworks and content areas, the four design principles drawn from the literature share common assumptions about learning. These assumptions include that learners build on what they already know and have established (e.g., multimodal communication skills, multilingual repertoires, home knowledge, cultural practices, and social relationships) and a learning environment can meaningfully support learning if learners' resources are employed as valuable assets for learning. We do not believe that these four design principles directly advance learners' critical sтем literacy. Rather, we used these four principles to create a learning environment that affords our reimagination of STEM education toward equity, social justice, and transformative purposes in culturally and linguistically diverse learning settings. Below, we discuss these four design principles drawing on literature and showcase how each principle supported teens' learning in Project RESET.

\subsection{Multimodality}

Multimodality provides a unique tool to engage learners in learning practices and to examine their participation in the moment. Multimodality is important in working with any learner but in particular with multilingual students because their cognitive and social engagement may be unnoticed if we focus solely on languages. To discuss multimodality as a design principle, we first define mode as "socially shaped and culturally given resources for making meaning" (Kress, 2009, p. 54). Kress asserted that the specifics of what counts as a mode is determined within a community because the meaning potential of a certain semiotic resource differs widely across different communities. For instance, while image might count as a mode in non-chemist communities, thus constituting one mode, molecular images and macroscopic images may be perceived distinctly as different modes by chemists (Johnstone, 1991). Within the scope of our work, wherein learners and instructors have ongoing conversations for scientific meaning making, we are interested in bodily engagement (e.g., gesture, posture, and gaze), voice quality (e.g., intonation and pitch), pause and silence, laughter, writing and images used in conversation, and use of space as distinct modes of communication. 
The idea of multimodality is that communication, regardless whether the communication is done through writing or speech, simultaneously involves multiple modes that are distinct and possess their own meaning potentials (Kress, 2009). This perspective transcends language-focused perspectives of communication and recognizes that language conveys only limited meanings. Science teaching and learning is inherently multimodal since science practices routinely involve texts, diagrams, gestures, and materials (Grapin, 2019; Kress, Jewitt, Ogborn, \& Tsatsarelis, 2001; Tang, Delgado, \& Moje, 2014). In addition, the action of participation in the moment of learning is a multimodal accomplishment among social actors and between social actors and their environments (Norris \& Jones, 2005; Siry \& Gorges, 2019). Use of non-linguistic modes (e.g., bodily engagement, interactions with and composition of artifacts) is not auxiliary to language, but equally as important as use of language, in socially mediated learning. This perspective encourages teachers and researchers to revisit the participation enacted by emergent multilingual youths and move away from deficit views on the use of non-linguistic modes.

In designing and implementing the afterschool program, we adapted the idea of multimodality in three different ways. First, we paid close attention to non-verbal participation and learning in understanding youths' participation and our facilitation of their learning. For instance, many newcomers tended to stay quiet in our program, which can be viewed as non-participation or a lack of interest. Yet, our close attention to their multimodal engagement revealed that they participated non-verbally, sometimes by looking at and reading poster paper closely or drawing their ideas on paper (Figures 1 and 2). Another revealing example is the facilitators' bodily engagement with the youth. Through a review of video data, we found out that while moderating a small-group discussion, facilitators, who do not speak the participants' languages, tended to orient their bodies toward more English-proficient teens in the group. This body positioning and resultant use of space can shape a participation structure that may further exclude newcomers who are still in the process of developing their English proficiency. This observation made us realize the subconscious bias and helped modify our facilitation practices.

Second, we promoted building of positive emotional energy and solidarity through multimodal participation (Collins, 2004; Wilmes \& Siry, 2018). In his research on interaction ritual chains, Collins argued that mutual focus of attention and shared mood in an interaction ritual can intensify each other, which in turn contributes to individuals' emotional energy and a group's solidarity. Thus, a focus on bodily orientation, facial expressions, and sounds such as voice quality and laughter is critical in order to examine successes of an 


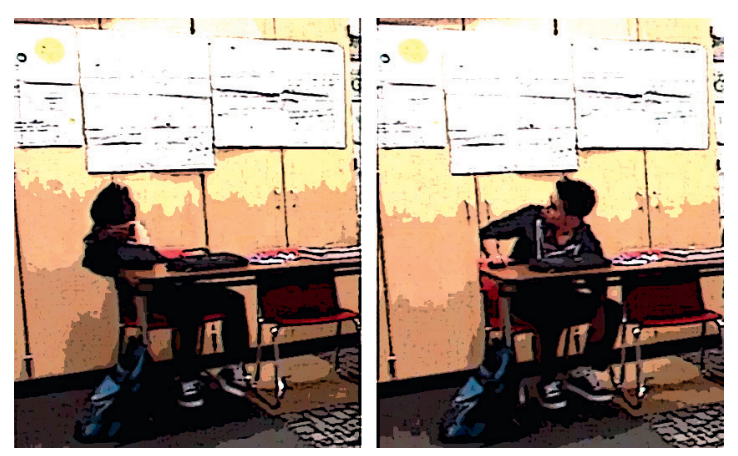

FIGURE 1 Jon was 19 years old and in 1oth grade. He had lived in the United States less than a year and spoke very limited English. Perhaps due to his limited English proficiency, he remained quiet in the program. In these images, turning his back, Jon is attentively looking at peers' work on chart paper from the week before. He maintained this posture for over 40 seconds.

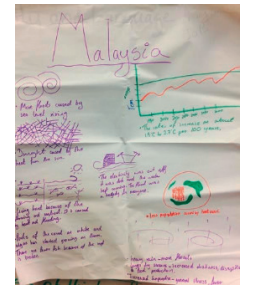
FIGURE 2
Chart paper that describes the impact of climate change in Malaysia generated by Jon and Apple. Most writing (in purple) was done by Apple, whereas most drawing (in green and orange) was done by Jon.

interaction ritual in developing solidarity among participants. In our program, we hoped to build positive emotional energy and solidarity, which would help their development of membership in the learning community, participation, and learning. We arranged the seats so that learners could sit closely to each other or move around to orient their bodies to shared physical artifacts (e.g., presentation chart paper). In addition, laughter was common throughout the program. We designed learning activities that led to laughter and let learners initiate laughter in whole-group and small-group discussions and tasks. While laughing, they aligned their bodies in a rhythmic way, which indicated their "collective effervescence" (Collins, 2004). We believe frequent occurrence of collective effervescence eased the learners' anxiety and encouraged their active participation (Figure 3 ).

Third, we employed the use of diverse semiotic resources and material artifacts to engage students (e.g., body, book, pen and paper, and computer) 


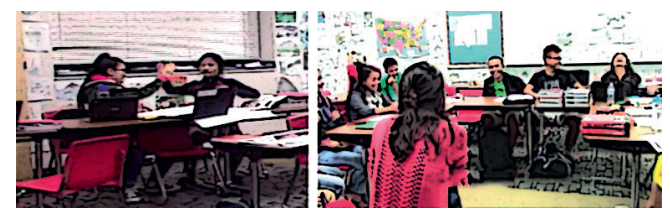

FIGURE 3 Multimodal engagement that indicates positive emotional energy. On the left, Thiri and Da Zin raise their arms and slap each other's open palm to encourage each other in completing the given task. On the right, a participant made a joke while presenting their pair's ideas, which led to a loud laughter from most participants.
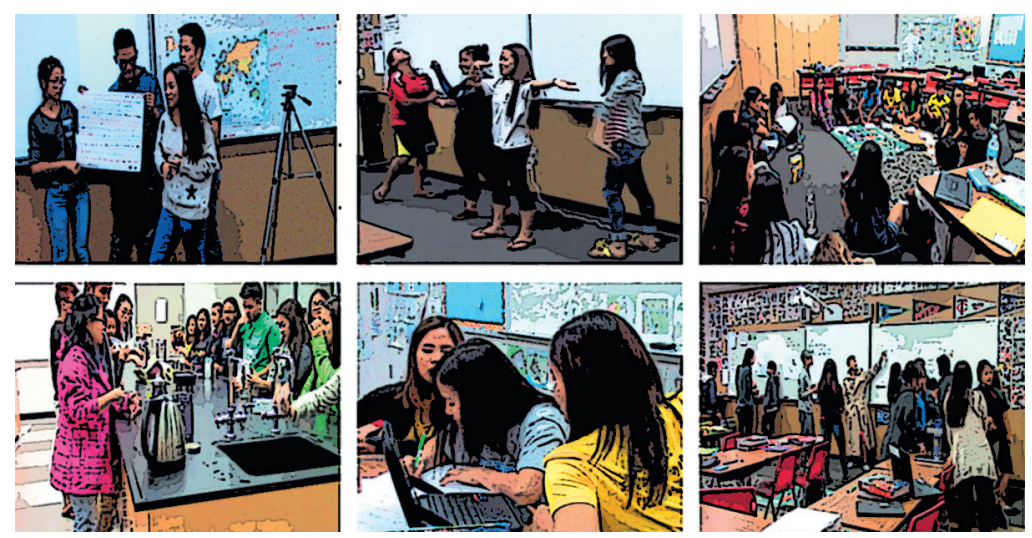

FIGURE 4 Examples of different activities that allowed various semiotic resources and participation structures

since different resources have different affordances (Figure 4). For instance, early in the program, we asked the learners to express weather phenomena non-verbally using only bodily movements; learners used online or physical books that have ample meaning-making resources, such as picture and graphs; and we used different presentation tools for learners, including slide presentations, chart paper gallery walks, and post-it notes. We encouraged learners to use both language and visuals in presenting their ideas. Mirroring our practice, teens often encouraged their peers to draw visuals to express their ideas especially when those peers' English proficiency was limited. 


\subsection{Funds of Knowledge}

A fund of knowledge was originally defined as home-based knowledge and practices that can be leveraged in school learning (Moll, Amanti, Neff, \& Gonzalez, 1992). Since the inception of the idea nearly 30 years ago, many researchers have expanded its scope into the broader public sphere and have striven to incorporate students' everyday experiences, practices, and values to foster their science learning and the construction of positive identities as science learners. In this expanded sense, students' funds of knowledge may include transnational experiences of immigrant students and youth pop culture (Moje et al., 2004), skills and talents in various activities such as storytelling that are not often sanctioned in traditional science classes (Tan \& Calabrese Barton, 2008), knowledge learned from the streets and students' ethnic communities (Calabrese Barton, Tan, \& Rivet, 2008), and non-school related labor experiences (Seiler, 2001). By identifying and utilizing students' funds of knowledge as valuable assets for new learning, classroom learning environments can support robust science learning of racially and linguistically non-dominant students. Teachers dialogically interact with learners who are already adept at a range of skills and discourses with which teachers are not familiar. Such interactions position learners as "important and powerful participants in their own learning and that of their peers and teachers, and also as members of a larger global society who can leverage their lives in schools towards making a change" (Calabrese Barton et al., 2011, pp. 6-7).

We made multiple efforts to identify and draw on the learners' funds of knowledge. Before designing the program, we interviewed teens from Burmese Organization to examine their identity construction and identify their experiences, knowledge, and practices that can be leveraged in designing the afterschool program (Ryu \& Tuvilla, 2018). From these interviews, we learned that the teens were eager to share their stories, valued their multilingualism, and developed a keen awareness of inequity, empathy for people in despair, and a pursuit of social justice. In the interview setting, they did so by re-authoring Chin and refugee narratives to be about hope and about being a change-maker toward a more equitable society. In designing the program, we leveraged these funds of knowledge by providing opportunities for storytelling and orienting the teens toward equity issues related to climate change. For instance, early in the program, we casually shared interesting experiences of weather phenomena. Some learners talked about a plant-based cream that Chin people applied to their face in order to protect their skin from sunburn and stay cool. They also talked about an insect that appears after rain in the Chin State and shared their varied experiences with that insect (e.g., some people eat the insect while 
some use it for fishing). Later in the program, we designed a learning activity titled "my weather story" wherein youth prepared a multimodal presentation of their weather experiences and presented it to the whole group. In addition, we designed learning activities that explored how climate change has different impacts on people based on their geographic locations, socioeconomic status, and political contexts in the global society.

While implementing the program, it was important to recognize how the youths used funds of knowledge in the moment of learning and negotiated their identities by mobilizing their own and peers' funds of knowledge. As detailed in another paper (Ryu, Tuvilla, \& Wright, 2019), the teens in the program effectively blended joking and science discourse in presenting their uncertain ideas, took up opportunities to share their experiences and knowledge from home, and coordinated turn-taking for equitable participation. By doing so, they validated their funds of knowledge as important assets for participation and learning and positioned themselves and peers as individuals situated within unique histories and cultural experiences that contribute unique values to knowledge construction (Calabrese Barton \& Tan, 2009). Importantly, by utilizing different funds of knowledge, they enacted multiple aspects of their identities, such as a humorous teen, capable science learner, a Chin person who is knowledgeable of their cultural practices, and an individual who cares about equity and fairness. We believe that our attention to and learners' agentive mobilization of funds of knowledge was reciprocal in that our provision of a learning space that values funds of knowledge enabled the teens to actively draw on their own, which in turn led us to build learning activities employing their funds of knowledge. Together they made the learning environment more flexible but critical in reconceptualizing what counts as knowledge (e.g., whose knowledge resources enter the knowledge construction space) and learning (e.g., what the goal of learning should be).

\subsection{Translanguaging}

The idea of translanguaging was originally introduced as a pedagogical practice for bilingual education, "purposeful concurrent uses of two languages in a bilingual classroom" (Lewis, Jones, \& Baker, 2012, p. 644), in Wales in which young learners were expected to learn and use Welsh and English fluently. As translanguaging gained traction among scholars internationally, its meaning has also expanded to incorporate "the flexible use of linguistic resources by multilingual speakers" (Blackledge \& Creese, 2014, p. 11, emphasis added), especially the naturally occurring everyday use of multiple languages to make sense of the world around them (García, 2009). In this sense, translanguaging 
practices include, but are not limited to, code-switching, translating for communicative partners, and borrowing words from one language to another. MacSwan (2017) further argued in his "integrated multilingual model" that all individuals, even so-called monolinguals, are in fact multilinguals as people develop a certain level of competence in and familiarity to multiple languages through participation in various speech communities.

Building on the recent conceptualization of translanguaging, we focus on everyday use of multiple languages and potential affordances of the hybrid language use for ST EM learning and participation. Multilingual youth can successfully engage in STEM meaning making when they use multiple discourses and languages to practice scientific inquiry (Rosebery, Warren, \& Conant, 1992) and mathematical problem-solving (Langer-Osuna, Moschkovich, Norén, Powell, \& Vazquez, 2016). When translanguaging is allowed and actively employed in a learning setting, emergent multilingual learners can participate in scientific sense making and also learn the language of instruction by doing the work of science (Lee, Quinn, \& Valdes, 2013). Learning environments that validate and value translanguaging empower users of non-dominant languages and emergent multilingual learners by encouraging them to use their full linguistic repertoire and legitimatizing their everyday language use (MacSwan, 2017; Poza, 2017). Through these flexible linguistic practices in environments that use epistemic openness as a tool for meaning making (Vossoughi, 2014), multilingual teens not only learn and use multiple languages, but use their languages as "funds of strategies" (Daniel, 2018) to achieve social, academic, and life goals (Daniel \& Pacheco, 2015).

There have been numerous recommendations on how to employ translanguaging practices in STEM instruction (Bravo, Heibert, \& Pearson, 2007; Lee, Lewis, Adamson, Maerten-Rivera, \& Secada; 2008; Swanson, Bianchini, \& Lee, 2014), yet research has not yet provided an adequate answer to a question regarding translanguaging in situations where teachers or educators do not know the languages of their students and thus cannot model the practice or moderate language work done in students' languages. Given the increase of superdiverse classrooms where students' linguistic backgrounds vary widely (Ricketts, Ryu, Tuvilla, Nardo, \& Love, in press), it is important to explore how to facilitate students' translanguaging for their learning and participation when instructors do not know students' languages. In our afterschool program, no one from our research team spoke or understood any of the multiple languages that the teens used other than English.

Here, we discuss three ways we applied translanguaging in our afterschool program while not speaking teens' languages. First, we drew on Bunch's (2014) 


\section{Three seasons in Chin State \\ - Hot (Tthal) \\ - Rain (Sur) \\ - Cold (Khuasik)}

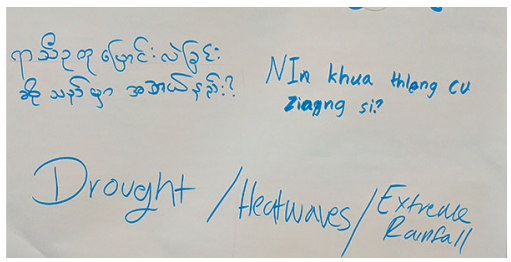

FIGURE 5 Examples of mixing languages in student-generated multimodal writing

finding that multilingual students tend to use their home languages more frequently when engaging in the language of ideas (e.g., small-group settings and generating and discussing new ideas), whereas they use the dominant language (English in U.S. schools) more frequently when engaging in the language of display. In our program, we designed different kinds of learning activities that had different purposes and created different participation structures, such as work in pairs, small groups, and the whole group for reading, online research, hands-on experiments, games, or presentations. We also used different formats of communication, such as an oral presentation, gallery walk/share out, and video creation. In particular, in the video production, some teens created a video with interviews conducted in their home language that was dubbed with an English translation. Our hope was that learners could use languages familiar to them in a small-group setting or for generating new knowledge and perhaps use English in the whole-group setting or for sharing their learning. Our analysis indeed showed that learners flexibly used multiple languages and used familiar languages in a small-group setting to explain science ideas, discuss cross-cutting concepts, provide task-related social support, and ensure everyone understands (Daniel, Ryu, Tuvilla, \& Wright, under review; Figure 5).

Second, we reminded and implicitly and explicitly encouraged learners to use their familiar languages when needed. To create an environment that welcomed multilingualism, facilitators often engaged in multilingual conversations, such as teaching and learning short phrases in non-English languages (Chin languages, Chinese, Tagalog, and Korean). We also designed activities where the teens translated key science ideas into their familiar language. When engaged in small-group activities, the participants naturally grouped themselves with their co-linguistic peers, who were also their close friends. This naturally allowed students to translanguage between English and familiar languages. Facilitators also frequently asked students to "make sure everyone in your group is on the same page." To this prompt, often the learners with higher English proficiency spoke in familiar languages to talk to peers with lower English proficiency and involved them in the sense-making process. 
Finally, we considered teens' use of home languages not as an indicator of limited English or distraction but as an indicator of engagement (see also Gonzales-Howard \& McNeil, 2016). We admit that it is difficult to moderate and facilitate participants' discussion when they were talking in non-English languages. Research also showed that learners sometimes switch to a nondominant language to engage in off-task conversations or communicate with each other without engaging teachers and dominant-language monolingual peers (Reyes, 2004; Ryu, 2015a). However, there is enough evidence that shows how multilingual learners utilize their full linguistic and knowledge resources to participate in meaning-making discourse and negotiate scientific meanings and participation positions. When teens were talking in their familiar languages, we tried to engage in the conversation multimodally (e.g., gaze and body posture) and sometimes asked them to translate for us. We believe this facilitation move can provide a validation of the use of multiple languages and temporarily position learners at a higher status since they possess more information than the instructors, which would further encourage their participation.

\subsection{Peer Relationship}

In a variety of learning settings, the frequency of employment of peer collaboration has been increasing. Using peer collaboration as a means for effective learning largely builds on learning theories of Vygotsky (1978), who argued that people learn through social interactions with more experienced peers. Instead of providing monologic lectures, teachers engage students in interactive learning practices, such as long-term group projects, in-class group discussion, and pair work (Cohen, 1994; Kibler, 2017). Practice- and collaboration-based teaching approaches allow students to learn from each other, experience the knowledge construction process, and apply the knowledge in authentic contexts. In STEM education, the goal of education moves away from simply instilling students with content knowledge, but incorporating science and engineering practices that scientists and engineers use for developing new knowledge (National Research Council, 2012). Thus, engaging in the doing of science through peer collaboration has become more important in recent years. Informal and afterschool learning environments provide an ideal space for peer collaboration because practices in informal settings are inherently collaborative and, unlike school classrooms, do not pose challenges such as assessment. Thus, in the designing of our program, we hoped to maximize peer-led collaborative learning.

Despite promises of peer collaboration, researchers have cautioned that peer collaboration may not equally support students from all backgrounds. More than 20 years ago, Cohen (1994) and Bianchini (1997) warned that 
students' social, peer, and academic status can interfere with their opportunities to participate in group work, which can lead to differences in the learning outcomes between low-status and high-status students. In a multilingual classroom, students' perceived English proficiency is another factor that influences their status and participation. Those with limited English proficiency are often positioned as novice, incompetent, and not cool. Thus, they are not invited to join a group or their contribution is devalued (Leki, 2001). Takeuchi's (2016) discourse analysis similarly showed that English learners participate in collaboration with an equitable footing when they group with friends while they were positioned as a novice in a teacher-assigned groups.

Perhaps, one way to mitigate the inequity in participation in multilingual learning settings could be to generate a learning environment in which learners develop peer relationships such as friendship, solidarity, and belongingness. As Takeuchi (2016) asserted, friendship is not static but dynamic and fluid and can develop through collaborative work as well. Solidarity can develop through embodied and emotional engagement in collective practices (Collins, 2004). A sense of belongingness or identity within a community can further members' participation and learning. We believe that peer relationship should be built within a climate of caring in the setting wherein instructors and students care for each other (Antrop-González \& De Jesús, 2006; Noddings, 2012). In such a learning environment, learners have access to the participation space, feel safe in sharing their ideas and being vulnerable with one another, and support each other's growth (Martin-Beltrán, Daniel, Peercy, \& Silverman, 2017).

We tried to support the teens' building of relationships in two different ways. First, we acknowledged the fact that any learning environment is simultaneously a content space and relational space (Barron, 2006). We also noted that the teens brought previously developed friendship and other kinds of peer relationships (either supportive or adversarial) to our learning setting. Thus, studentinitiated activities that potentially strengthen their peer relationship were encouraged. Close friends often sat close to each other, engaged in the group work together, and conversed about topics of their interests. We have observed that teens watched Korean television shows, practiced Chinese language, talked about soccer, and looked up the map of Chin State before the program meetings or alongside with activities during the program meetings. Perceiving friendship and supportive relationships as important assets for learning, we engaged ourselves in their conversation or let them continue their "off-task activities" with a hope that this would strengthen their existing relationship.

Additionally, we hoped the teens could build new, supportive relationships with those who they had not known. Although all the teens were Chin people, they had built their small social circles primarily based on their home 
languages, churches, and English proficiency. They did not voluntarily mingle and socialize with those whom they were not familiar with. To break the social boundaries, we occasionally started to mix students up during group work. We note that we did so after the mid-point of the year, when presumably learners were familiar with us and the learning activities. When mixing them up, we tried to be transparent as to why we wanted them to move out of their comfort zone of friend groups by saying that "We would like to mix people, so you work with people you don't know that well." In response to new grouping practice, some teens voluntarily chose to work with newcomers whose English proficiency was rudimentary. We also observed that newcomers showed their vulnerability, and, in response, more English-proficient peers expressed empathy, which we see as a beginning of trust-building and care for each other. Another teen supported newcomers by providing content support, such as explaining new English words, teaching the correct spelling of new words, and explaining scientific content. We believe peer relationships are one of the key aspects of the program that supported teens' participation, especially among newcomers who are unfamiliar with the U.S. learning environment and our program.

\section{Implications for Science Education in Asia and the Pacific Regions}

As mentioned earlier, many people in Asia and the Pacific Regions (APR) leave their home countries because of life-threatening living conditions and enter another APR country as either their first asylum country before resettlement or a resettlement country. It is noteworthy that globally only $1 \%$ of refugees have resettled in mostly developed countries, while the majority of refugees live in neighboring low-income countries, mostly in refugee camps, for periods of several years to even decades (Dryden-Peterson, 2016). The trend is similar in APR. Several wealthy countries ratified one or more of UNHCR's refugee conventions (UNHCR, 2014), including Australia, Japan, and South Korea, yet they accept only limited numbers of asylum seekers or resettlement. For example, between 2013-2017, Japan accepted less than 30 refugees each year - less than $1 \%$ of asylum seekers are granted the status (Chan, 2018; Moon, 2016). In contrast, countries such as Bangladesh, Nepal, Malaysia, Thailand, and Pakistan host a large number of refugees primarily from Myanmar, Afghanistan, and Bhutan. Some of these hosting countries have shown hospitality and support toward refugees (UNHCR, 2O19b), but these countries have not ratified UNHCR's refugee conventions. Thus, in these countries, refugees are exposed to a potential risk of arrest as undocumented migrants and generally do not have access to public services such as healthcare and education. 
In this APR context, our study has several different implications for science education in APR. We first discuss implications for countries that accept refugee resettlement. In these countries, resettled refugee children and youth are enrolled in the hosting country's national public school systems. We argue that expanding asset-based approaches in formal and informal science education is most important both in teaching science to former refugees and as a foundational step toward equitable and socially just science education. Science teachers and education researchers should move away from viewing refugee youth only as helpless victims that need the support of the host society and assuming their assimilation to it should be the goal of refugee education. Instead, assetbased approaches would value heterogeneity as an important asset for learning and actively identify learners' strengths (e.g., multilingualism, cultural practices and knowledge, and orientation to social justice). Once identified, these strengths should be utilized for their own and peers' science learning. In designing learning environments, teachers and students should collectively create a climate of care in addition to concerns about academic growth. South Korea's policy on multicultural education (Ministry of Education, Science, and Technology, 2012) is a good example of applying these principles to educational policies and programs at the national level. It seeks to build on multicultural students' bilingualism and talents and change school cultures to foster caring and integration through the education of non-multicultural students and parents. However, we believe that further research should be conducted to examine how such governmental level policies are actually implemented.

Perhaps what is more challenging is to address science education in countries of refugees' first asylum - the countries to which refugees first flee after crossing a national border. As mentioned above, these countries typically do not provide refugee youth access to the national public education system. Even in countries that provide primary education for refugees, secondary and postsecondary education is severely restricted for refugee youth (Dryden-Peterson, 2016; Prodip, 2017). On the one hand, we believe that those countries should expand refugees' rights to participate in public education. On the other, we as science educators and education researchers should generate understanding of these refugee children's realities and experiences of education. Criticizing the field's lack of knowledge about refugee children's educational experiences in first asylum countries, Dryden-Peterson (2016) argued that "pre-resettlement education experiences of refugee children constitute a 'black box' in their post-resettlement education" (p. 133). What educational opportunities are provided? What science do they learn? What science knowledge and practices do they value and would they like to learn? More knowledge in pre-settlement education would not only help educators in their resettlement countries better 
facilitate resettled refugees' learning, but also urge educators and researchers to reimagine the education of children in first asylum countries.

In the first asylum countries, many refugee communities develop independent education systems within refugee camps or communities - called refugee schools - often unbeknownst to the government of the host country (Oh \& van der Stouwe, 2008; O'Neal et al., 2018). These schools often reflect the educational needs of refugee communities, such as integrating religious education and education of ethnic languages while teaching standardized academic content (Dryden-Peterson, 2016), and students, parents, and educators are highly motivated to pursue education. These refugee schools are places to reimagine the science education of refugee youth. Schools can be places that incorporate these students' use of multimodality and multiple languages and draw on their funds of knowledge. These schools might provide an ideal space to create a climate of care, foster students' understanding of inequity, and connect the understanding to science learning (e.g., health science and climate science). Many refugee schools are challenged by limited financial resources, limited teacher training, and potential conflicts with the host society (Brown, 2001). This unique situation calls for international collaboration among scholars, practitioners, refugee community members, and UNHCR or other nongovernmental organizations.

Increasing border crossing between countries around the world in recent years implies that societies, regardless of where they are, are becoming more diverse culturally and linguistically than before. Refugees constitute an important part of this global picture. In this increasingly diverse global context, we believe that the goals and directions of science education should be revisited. We conclude our paper by asking questions for educators and researchers living in this changing global context: What goals and outcomes should we pursue in the work of scientific meaning making? What are replicable processes to achieve those goals and outcomes? What learning environments enable such processes, and what de facto learning environments exist in the current moment? We believe that educators and researchers should critically and constantly ask and answer those questions in pursuing their work.

\section{Acknowledgements}

We would like to thank the Burmese Organization and the youth participants for participation in this work; Mavreen Tuvilla and Casey Wright for their work throughout the process of this project as graduate research assistants; Tiffany Sikorski, who provided feedback in the early design of the project; and Khen, 
Cherry, Emily, and Suitintial who offered valuable insights in translation of the data and understanding of Chin cultures and languages.

\section{Funding}

This work was supported by the National Science Foundation of the United States (NSF DRL \#1612688).

\section{Ethical Considerations}

Approval to conduct this study was granted by Institutional Review Board of Purdue University, Vanderbilt University, and University of Illinois at Chicago. The data collected from this project was obtained with the necessary clearance from guardians and the teens involved in the study. The names of the school and participants used in this study are all pseudonyms.

\section{About the Authors}

Minjung Ryu is an assistant professor in Chemistry and Learning Sciences at University of Illinois at Chicago, USA. Her research focuses on STEM learning and participation of cultural and linguistic minority students. Employing ethnography and discourse analysis, she examines how racial, ethnic, and linguistic minority students engage in STEM discourses using multilingual and multimodal means and what are ways to design learning environments to improve these students' learning experiences. She also has collaborated with high school science teachers to develop instructional materials and practices to support English learners in linguistically superdiverse classrooms.

Shannon Mary Daniel is an associate professor at Vanderbilt University's Peabody College, USA. Her work supports teachers in seeing, responding to, and leveraging multilingual learners' strengths and strategies. Toward this end, Shannon investigates refugee youths' strategies for success across contexts, multilingual youths' ways of supporting one another in school-based literacy learning, and educators' planned and responsive scaffolding of literacy and language learning. Another central line of her research is how teachers learn to educate multilingual learners, both during pre-service teacher education and in-service professional development across their careers. 


\section{References}

Antrop-González, R., \& De Jesús, A. (2006). Toward a theory of critical care in urban small school reform: examining structures and pedagogies of caring in two Latino community-based schools. International Journal of Qualitative Studies in Education, 19(4), 409-433.

Bang, M., \& Medin, D. (2010). Cultural processes in science education: Supporting the navigation of multiple epistemologies. Science Education, 94(6), 1008-1026.

Bang, M., \& Vossoughi, S. (2016). Participatory design research and educational justice: Studying learning and relations within social change making. Cognition and Instruction, 34(3), 173-193. doi:10.1080/o73700o8.2016.1181879.

Barron, B. (2006). Interest and self-sustained learning as catalysts of development: A learning ecology perspective. Human development, 49(4), 193-224.

Bell, P., Lewenstein, B., Shouse, A. W., \& Feder, M. A. (2009). Learning Science in Informal Environments: People, Places, and Pursuits. Washington, DC: National Academies Press.

Bianchini, J. A. (1997). Where knowledge construction, equity, and context intersect: Student learning of science in small groups. Journal of Research in Science Teaching, 34(10), 1039-1065.

Blackledge, A., \& Creese, A. (2014). Heteroglossia as practice and pedagogy. Springer.

Booker, A., \& Goldman, S. (2016). Participatory design research as a practice for systemic repair: Doing hand-in-hand math research with families. Cognition and Instruction, 34(3), 222-235.

Bravo, M. A., Hiebert, E. H., \& Pearson, P. D. (2007). Tapping the Linguistic Resources of Spanish-English Bilinguals. Vocabulary acquisition: Implications for reading comprehension, $140-156$.

Brown, T. (2001). Improving quality and attainment in refugee schools: The case of the Bhutanese refugees in Nepal. In Learning for a Future: Refugee Education in Developing Countries (pp. 109-162). United Nations Publications.

Bunch, G.C.(2014). The language of ideas and thelanguage of display:Reconceptualizing "academic language" in linguistically diverse classrooms. International Multilingual Research Journal, 8(1), 70-86.

Calabrese Barton, A., Basu, S. J., \& Tan, E. (2011). Introduction. In S. J. Basu, A. C. Barton, \& E. Tan (Eds.), Democratic Science Teaching: Building the Expertise to Empower Low-Income Minority Youth in Science (pp. 1-20). Rotterdam, The Netherlands: Sense Publishers.

Calabrese Barton, A., \& Tan, E. (2009). Funds of knowledge and discourses and hybrid space. Journal of Research in Science Teaching, 46(1), 50-73.

Calabrese Barton, A., \& Tan, E. (2010). We be burnin'! Agency, identity, and science learning. The Journal of the Learning Sciences, 19, 187-229. 
Calabrese Barton, A., Tan, E., \& Rivet, A. (2008). Creating hybrid spaces for engaging school science among urban middle school girls. American Educational Research Journal, 45(1), 68-103.

Chan, T. F. (2018). No Entry: How Japan's shockingly low refugee intake is shaped by the paradox of isolation, a demographic time bomb, and the fear of North Korea. Business Insider. Retrieved from https://www.businessinsider.com/why-japan -accepts-so-few-refugees-2018-4.

Chow, S. (2018). "Chin": Who Are the Chin Refugees? Retrieved from https://www.rage .com.my/refugeesnomore-chin/.

Cohen, E. G. (1994). Restructuring the classroom: Conditions for productive small groups. Review of Educational Research, 64(1), 1-35.

Collins, R. (2004). Interaction Ritual Chains. Princeton University Press.

Daniel, S. M. (2018). Resettled refugee youth leveraging their out-of-school literacy practices to accomplish schoolwork. Mind, Culture, and Activity, 25(3), 263-277.

Daniel, S. M., \& Pacheco, M. B. (2016). Translanguaging practices and perspectives of four multilingual teens. Journal of Adolescent \& Adult Literacy, 59(6), 653-663.

Daniel, S., Ryu, M., Tuvilla, M. R. S., \& Wright, C. E. (under review). The affordances of leveraging multilingual repertoires in scientific reasoning among resettled refugee teens. To be included in A. Jacobsson, A. Karlsson, \& P. N. Larsson (Eds.), Translanguaging in science education. Springer.

Dryden-Peterson, S. (2016). Refugee education in countries of first asylum: Breaking open the black box of pre-resettlement experiences. Theory and Research in Education, 14(2), 131-148.

Emdin, C. (2011). Citizenship and the three C's. In S. Jhumki Basu, A. Calabrese Barton, \& E. Tan (Eds.), Democratic science teaching: Building the expertise to empower lowincome minority youth in science (pp. 103-114). Springer.

García, O. (2009). Bilingual education in the 21st century: A global perspective. Wiley-Blackwell.

González-Howard, M., \& McNeill, K. L. (2016). Learning in a community of practice: Factors impacting English-learning students' engagement in scientific argumentation. Journal of Research in Science Teaching, 53(4), 527-553.

Grapin, S. (2019). Multimodality in the new content standards era: Implications for English learners. TE SOL Quarterly, 53(1), 30-55.

Gutiérrez, K. D., Baquedano-López, P., \& Tejeda, C. (1999). Rethinking diversity: Hybridity and hybrid language practices in the third space. Mind, Culture, and Activity, 6(4), 286-303.

Jewitt, C., Kress, G., Ogborn, J., \& Tsatsarelis, C. (2001). Exploring learning through visual, actional and linguistic communication: The multimodal environment of a science classroom. Educational Review, 53(1), 5-18. 
Johnstone, A. H. (1991). Why is science difficult to learn? Things are seldom what they seem. Journal of Computer Assisted Learning, 7, 75-83.

Jolliffe, K. (2015). Ethnic Armed Conflict and Territorial Administration in Myanmar. Retrieved from http://asiafoundation.org/publication/ethnic-armed-conflict-and -territorial-administration-in-myanmar-full-report/.

Kang, N.-H. (2019). A review of the effect of integrated STEM or STEAM (science, technology, engineering, arts, and mathematics) education in South Korea. Asia-Pacific Science Education, 5(1), 1-22.

Kibler, A. (2017). Peer interaction and learning in multilingual settings from a sociocultural perspective: Theoretical insights. International Multilingual Research Journal, $11(3), 199-203$.

Kress, G. (2009). What is mode? In C. Jewitt (Ed.), The Routledge Handbook of Multimodal Analysis (pp. 54-67). New York, NY: Routledge.

Langer-Osuna, J. M., Moschkovich, J., Norén, E., Powell, A. B., \& Vazquez, S. (2016). Student Agency and Counter-Narratives in Diverse Multilingual Mathematics Classrooms: Challenging Deficit Perspectives. In Mathematics Education and Language Diversity (pp. 163-173): Springer.

Lee, O., Lewis, S., Adamson, K., Maerten-Rivera, J., \& Secada, W. G. (2008). Urban elementary school teachers' knowledge and practices in teaching science to English language learners. Science Education, 92(4), 733-758.

Lee, O., Quinn, H., \& Valdés, G. (2013). Science and language for English language learners in relation to Next Generation Science Standards and with implications for Common Core State Standards for English language arts and mathematics. Educational Researcher, 42(4), 223-233.

Leki, I. (2001). "A narrow thinking system": Nonnative-English-speaking students in group projects across the curriculum. TESOL Quarterly, 35(1), 39-67.

Lewis, G., Jones, B., \& Baker, C. (2012). Translanguaging: Origins and development from school to street and beyond. Educational Research and Evaluation, 18(7), 641-654.

MacSwan, J. (2017). A Multilingual Perspective on Translanguaging. American Educational Research Journal, 54(1), 167-201.

Martin-Beltrán, M., Daniel, S., Peercy, M., \& Silverman, R. (2017). Developing a zone of relevance: Emergent bilinguals' use of social, linguistic, and cognitive support in peer-led literacy discussions. International Multilingual Research Journal, 11(3), 152-166.

Ministry of Education, S., and Technology. (2012). 다문화학생 교육 선진화 방안 (Plans to advance education of multicultural students). Retrieved from http://www.korea .kr/archive/expDocView.do?docId=31295.

Moje, E. B., Ciechanowski, K. M., Kramer, K., Ellis, L., Carrillo, R., \& Collazo, T. (2004). Working toward third space in content area literacy: An examination of everyday funds of knowledge and Discourse. Reading Research Quarterly, 39(1), 38-70. 
Moll, L. C., Amanti, C., Neff, D., \& Gonzalez, N. (1992). Funds of knowledge for teaching: Using a qualitative approach to connect homes and classrooms. Theory Into Practice, 31, 132-141.

Moon, K. H. S. (2016). Why is Asia MIA on refugees? Retrieved from https://www.brook ings.edu/blog/order-from-chaos/2016/og/22/why-is-asia-mia-on-refugees/.

National Academies of Sciences, Engineering, and Medicine. (2018). English Learners in STEM Subjects: Transforming Classrooms, Schools, and Lives. The National Academies Press.

National Academy of Engineering, \& National Research Council. (2014). STEM Integration in K-12 Education: Status, Prospects, and an Agenda for Research. The National Academies Press.

National Research Council. (2012). A framework for K-12 science education: Practices, crosscutting concepts, and core ideas. Washington, D.C.: The National Academy Press.

National Research Council. (2015). Identifying and Supporting Productive STEM Programs in Out-of-School Settings. The National Academies Press.

Noddings, N. (2012). The caring relation in teaching. Oxford Review of Education, 38(6), 771-781.

Norris, S., \& Jones, R. H. (2005). Discourse in action: Introducing mediated discourse analysis. Routledge.

O’Neal, C., Atapattu, R., Jegathesan, A., Clement, J., Ong, E., \& Ganesan, A. (2018). Classroom management and socioemotional functioning of Burmese refugee students in Malaysia. Journal of Educational and Psychological Consultation, 28(1), 6-42.

O'Neill, T. (2011). Improvisation with/in science. In S. J. Basu, A. C. Barton, \& E. Tan (Eds.), Democratic science teaching: Building the expertise to empower low-income minority youth in science (pp. 41-54). Springer.

Oh, S.-A., \& Van Der Stouwe, M. (2008). Education, diversity, and inclusion in Burmese refugee camps in Thailand. Comparative Education Review, 52(4), 589-617.

Olitsky, S., Flohr, L. L., Gardner, J., \& Billups, M. (2010). Coherence, contradiction, and the development of school science identities. Journal of Research in Science Teaching, 47(10), 1209-1228.

Poza, L. (2017). Translanguaging: Definitions, Implications, and Further Needs in Burgeoning Inquiry. Berkeley Review of Education, 6(2), 101-128.

Prodip, M. A. (2017). Health and educational status of Rohingya refugee children in Bangladesh.Journal of Population and Social Studies [JPSS ], 25(2), 135-146.

Reyes, I. (2004). Functions of code switching in schoolchildren's conversations. Bilingual Research Journal, 28(1), 77-98. doi:http://dx.doi.org/10.1080/15235882.200 4.10162613. 
Ricketts, A., Ryu, M., Nardo, J. E., Tuvilla, M. R. S., \& Love, C. G. (in press). Science teaching and learning in linguistically super-diverse classrooms. In M. Atwater (Ed.), International Handbook of Multicultural Science Education.

Rosebery, A. S., Warren, B., \& Conant, F. R. (1992). Appropriating scientific discourse: Findings from language minority classrooms. Journal of the Learning Sciences, 2(1), $61-94$.

Ryu, M. (2015a). An examination of Melody's identities, contexts, and learning in a US science classroom: implications for science education of Asian transnational students. Asia-Pacific Science Education, 1:4. doi:10.1186/s41029-015-0004-y.

Ryu, M. (2015b). Positionings of racial, ethnic, and linguistic minority students in high school biology class: Implications for science education in diverse classrooms. Journal of Research in Science Teaching, 52(3), 347-370.

Ryu, M., \& Tuvilla, M. R. S. (2018). Resettled refugee youths' stories of migration, schooling, and future: Challenging dominant narratives about refugees. The Urban Review, 50(4), 539-558.

Ryu, M., Tuvilla, M. R. S., \& Wright, C. E. (2019). Resettled Burmese refugee youths' identity work in an afterschool STEM learning setting. Journal of Research in Childhood Education, 33(1), 84-97.

Seiler, G. (2001). Reversing the "standard" direction: Science emerging from the lives of African American students. Journal of Research in Science Teaching: The Official Journal of the National Association for Research in Science Teaching, 38(9), 1000-1014.

Settlage, J., Madsen, A., \& Rustad, K. (2005). Inquiry Science, Sheltered Instruction, and English Language Learners: Conflicting Pedagogies in Highly Diverse Classrooms. Issues in Teacher Education, 14(1), 39-57.

Siry, C., \& Gorges, A. (2019). Young students' diverse resources for meaning making in science: learning from multilingual contexts. International Journal of Science Education, 1-23.

Srikoom, W., Hanuscin, D. L., \& Faikhamta, C. (2017). Perceptions of in-service teachers toward teaching STEM in Thailand. Asia-Pacific Forum on Science Learning and Teaching, 18(2), 1-23.

Swanson, L. H., Bianchini, J. A., \& Lee, J. S. (2014). Engaging in argument and communicating information: A case study of English language learners and their science teacher in an urban high school. Journal of Research in Science Teaching , 51(1), 31-64.

Takeuchi, M. A. (2016). Friendships and group work in linguistically diverse mathematics classrooms: Opportunities to learn for English language learners. Journal of the Learning Sciences, 25(3), 411-437.

Tan, E., \& Calabrese Barton, A. (2008). From peripheral to central, the story of Melanie's metamorphosis in an urban middle school science class. Science Education, 92, $567-59$ o. 
Tang, K. s., Delgado, C., \& Moje, E. B. (2014). An integrative framework for the analysis of multiple and multimodal representations for meaning-making in science education. Science Education, 98(2), 305-326.

United Nation Higher Commissioner for Refugees. (2014). Bureau for Asia and the Pacific Country Operations Fact Sheets. Retrieved from https://www.unhcr .org/531dd2159.pdf.

United Nation Higher Commissioner for Refugees. (2018-2019). Regional Summaries: Asia and the Pacific. Retrieved from https://www.unhcr.org/en-us/publications/ fundraising/5aobff9o7/unhcr-global-appeal-2018-2019-update-asia-pacific -regional-summary.html.

United Nation Higher Commissioner for Refugees. (2019a). Global Trends: Forced Displacement in 2019. Retrieved from https://www.unhcr.org/globaltrends2019/.

United Nation Higher Commissioner for Refugees. (2019b). Update on UNHCR's Operations in Asia and the Pacific. Retrieved from https://www.unhcr.org/5c7ff 52b4.pdf.

United Nation Higher Commissioner for Refugees. (2O20). UNHCR Concerned at Mounting Civilian Casualties and Displacement inWestern Myanmar. Retrieved from https://www.unhcr.org/en-us/news/briefing/2020/3/5e7 dbca44/unhcr-concerned -mounting-civilian-casualties-displacement-western-myanmar.html.

Upadhyay, B., \& Albrecht, N. (2011). Deliberative democracy in an urban elementary science classroom. In S. Jhumki Basu, A. Calabrese Barton, \& E. Tan (Eds.), Democratic science teaching: Building the expertise to empower low-income minority youth in science (pp. 75-87). Springer.

Vygotsky, L. S. (1978). Mind in society. Cambridge, MA: Harvard University Press.

Wilmes, S. E., \& Siry, C. (2018). Interaction rituals and inquiry-based science instruction: Analysis of student participation in small-group investigations in a multilingual classroom. Science Education, 102(5), 1107-1128.

Winn, P. (2017). The Biggest Group of Current Refugees in the US? Christians from Myanmar. Retrieved from https://www.pri.org/stories/2017-05-04/biggest-group -refugees-us-christians-myanmar. 